\title{
Igf2r and Igf2 gene expression in androgenetic, gynogenetic, and parthenogenetic preimplantation mouse embryos: absence of regulation by genomic imprinting
}

\author{
Keith E. Latham, ${ }^{1,4}$ Adam S. Doherty, ${ }^{2}$ Carolyn D. Scott, ${ }^{3}$ and Richard M. Schultz ${ }^{2}$ \\ ${ }^{1}$ Temple University School of Medicine, Department of Biochemistry and The Fels Institute for Cancer Research and \\ Molecular Biology, Philadelphia, Pennsylvania 19140 USA; ${ }^{2}$ Department of Biology, University of Pennsylvania, \\ Philadelphia, Pennsylvania 19104-6018 USA; ${ }^{3}$ Royal Prince Alfred Hospital, Department of Endocrinology, Camperdown, \\ NSW 2050, Australia
}

Genomic imprinting in mammals is believed to result from modifications to chromosomes during gametogenesis that inactivate the paternal or maternal allele. The genes encoding the insulin-like growth factor type 2 (Igf2) and its receptor $(I g f 2 r)$ are reciprocally imprinted and expressed from the paternal and maternal genomes, respectively, in the fetal and adult mouse. We find that both genes are expressed in androgenetic, gynogenetic, and parthenogenetic preimplantation mouse embryos. These results indicate that inactivation of imprinted genes occurs postfertilization (most likely postimplantation) and that genomic imprinting and gene inactivation are separate processes. We propose that imprinting marks the chromosome so that regulatory factors expressed in cells at later times can recognize the imprint and selectively inactivate the maternal or paternal allele. For these genes, this finding invalidates models of genomic imprinting that require them to be inactive from the time of fertilization.

[Key Words: Genomic imprinting; preimplantation mouse embryo; Igf2; Igf2r; androgenone; gynogenone]

Received October 27, 1993; revised version accepted December 9, 1993.

In mammals genomic imprinting leads to differences in allelic expression for a number of genes according to their parental origin. As a result, embryos with two maternal sets of chromosomes (gynogenones and parthenogenones) or two paternal sets (androgenones) fail to develop to term and exhibit somewhat complementary phenotypic abnormalities (Kaufman et al. 1977; Barton et al. 1984; McGrath and Solter 1984; Surani et al. 1984, 1986, 1987; Thomson and Solter 1989). For example, the development of the embryo proper is more complete in gynogenones, whereas development of extraembryonic tissues is more extensive in androgenones.

In mammals, genomic imprinting is defined in a functional sense. A paternally imprinted gene is expressed from the maternal genome, whereas a maternally imprinted gene is expressed from the paternal genome. It is also widely assumed, but not yet proven, that differences in the abilities of imprinted alleles expressed are established during gametogenesis. This assumption represents a departure from the original definition of chromo-

${ }^{4}$ Corresponding author. somal imprinting as simply a mark that the cell can use to distinguish different alleles (Crouse 1960).

Several imprinted genes have been identified, including the insulin-like growth factor type 2 (Igf2) gene, the insulin-like growth factor type 2 receptor $(\operatorname{Ig} f 2 r \mid$ gene, the $H 19$ gene, and the small nuclear ribonucleoprotein polypeptide $\mathrm{N}$ gene (Barlow et al. 1991; Bartolomei et al. 1991; DeChiara et al. 1991; Leff et al. 1992). The mechanism $|\mathrm{s}|$ by which these and other genes become imprinted and inactivated is unknown. The genomic imprinting process must be both reversible and heritable so that during each generation the appropriate imprint can be established within the germ lineage and then propagated during embryogenesis. DNA methylation and heterochromatization have been proposed as possible mechanisms that would fulfill these requirements (Doerfler 1983; Hadchouel et al. 1987; Reik et al. 1987; Sapienza et al. 1987; Swain et al. 1987; Sasaki et al. 1992). Gameteof-origin-dependent differences in the degree of methylation are observed for a number of transgenes and, in some cases, affect transgene expression and DNase I hypersensitivity (Doerfler 1983; Hadchouel et al. 1987; 
Reik et al. 1987; Sapienza et al. 1987, 1989; Swain et al. 1987; Sasaki et al. 1992).

Results from transgenic studies reveal that both maternal and paternal patterns of transgene methylation are erased in primordial germ cells and become re-established during germ cell maturation (Chaillet et al. 1991; Ueda et al. 1992). Interestingly, whereas the maternal pattern of methylation is completely established during oogenesis, the paternal pattern of methylation of at least one transgene changes between days 3.5 and 6.5 of development (Chaillet et al. 1991), possibly as a consequence of the remodeling of the paternal genome (Howlett and Reik 1991). For the Igf2r gene, a maternal pattern of methylation in region 2 , which is within an intron, is also established during oogenesis, but a paternal pattern of methylation in region 1 , which encompasses the promoter and transcription start site, is established well after fertilization (Brandeis et al. 1993; Stoger et al. 1993). Allele-specific patterns of methylation are not detected for either the Igf2 gene or the $H 19$ gene in gametes and early cleavage-stage embryos (Brandeis et al. 1993). It has been suggested that the allele-specific patterns of methylation observed for the Igf2, Igf2r, and H19 genes in adult cells are established in a stepwise manner during embryogenesis and that only a select few methylation groups exist in the gamete and early embryo that denote parental identity of imprinted alleles.

It is not yet clear whether differential methylation determines the ability of an allele to be expressed or merely stabilizes an inactive state after it is established. A paradigm for studying methylation effects on gene expression is $\mathrm{X}$ chromosome inactivation. Although some $\mathrm{X}$-linked genes become methylated near the time of inactivation (Singer-Sam et al. 1990; Grant et al. 1992), other X-linked genes become methylated after inactivation, indicating that methylation may stabilize the inactive state (Kaslow and Migeon 1987; Lock et al. 1987). Moreover, selective paternal $\mathrm{X}$ inactivation in extraembryonic tissues, which is believed to reflect $\mathrm{X}$ chromosome imprinting, apparently does not involve permanent modifications of the DNA itself (Kratzer et al. 1983). In the midgestation fetus, the imprinted Igf2 gene, which is located on chromosome 7, does not exhibit parent-specific methylation or DNase I insensitivity in or around its promoter, but such methylation differences do exist farther upstream; and despite its potentially open chromatin conformation, only a very low level of expression of the maternal Igf2 gene is detected by reverse transcription polymerase chain reaction (RT-PCR) (Sasaki et al. 1992). In contrast, the nearby reciprocally imprinted $H 19$ gene exhibits paternal-specific hypermethylation and DNase I insensitivity (Ferguson-Smith et al. 1993; Bartolomei et al. 1993). Thus, the establishment of parentspecific methylation patterns and altered chromatin states may vary among imprinted genes or their promoters.

The absence of most of the parental-specific differences in methylation in gametes and early embryos, for both certain transgenes and endogenous genes (e.g., Igf2r, Igf2, and H19), raises the question of whether imprinted genes behave as if they are imprinted prior to the establishment of these methylation patterns. With one transgenic line, genetic background effects, as well as parental origin effects, are observed (Surani et al. 1990). The genetic background effects are attributed to modifier factors present in the egg cytoplasm that affect expression from the paternal genome but not the maternal genome (Surani et al. 1990; Engler et al. 1991). Consistent with this, the developmental potential of androgenetic mouse embryos is also influenced by factors in the egg (Latham and Solter 1991). Taken together, these observations in. dicate that inactivation of at least some imprinted genes probably involves epigenetic modifications that occur postfertilization as well as those that occur during gametogenesis. Given these observations, there is reason to suspect that the imprint established during gametogenesis may not be manifested as a difference in ability of an allele to be expressed until some time after fertilization.

To test this possibility, we examined the expression of the paternally imprinted $I g f 2 r$ gene and the maternally imprinted Igf2 gene in androgenetic, gynogenetic, parthenogenetic, and normal preimplantation stage mouse embryos. To do this, we used a semiquantitative RTPCR assay that allows comparison of the relative amounts of mRNAs present in embryos at either different stages of development or the same stage of development (Temeles et al. 1994). We find that androgenones at both the eight-cell and blastocyst stages express significant amounts of Igf2r mRNA and protein that are well in excess of what can be attributed to maternally derived Igf $2 r$ mRNA or protein. We also find that parthenogenetic blastocysts express significant amounts of Igf2 mRNA. These results indicate that the paternally imprinted Igf2r gene and the maternally imprinted Igf2 gene can be expressed throughout the preimplantation period and that the methylation differences between maternal and paternal genomes observed at fertilization are not sufficient to regulate allelic expression.

\section{Results \\ Igf $2 \mathrm{r} m R N A$ expression in normal embryos}

Our first objective was to measure changes in the relative amounts of Igf2r mRNA present in egg, two-, and eight-cell stage embryos to provide a quantitative basis to compare relative Igf2r mRNA abundances in eightcell androgenones, gynogenones, and normal embryos, particularly with regard to how much of this mRNA might be maternally derived by the eight-cell stage. To do this, we used a semiquantitative RT-PCR assay in which exogenously added globin mRNA serves as a control for RNA recovery and the efficiency of the RT-PCR reactions (Temeles et al. 1994). This assay permits the comparison of relative abundances of a particular mRNA in embryos at different stages of development or different types of embryos (e.g., androgenones vs. gynogenones) at the same stage of development. We have previously documented that the relative changes that we observe in actin mRNA abundance during preimplanta- 
tion development with this RT-PCR assay are very similar to those determined by Northern blot analysis (Temeles et al. 1994).

In contrast to an earlier report (Rappolee et al. 1992), we readily detected $I g f 2 r$ mRNA in the unfertilized egg (Fig. 1A,D). The Igf2r mRNA abundance declined sharply by the two-cell stage and then increased 15 -fold by the eight-cell stage. This trend-a decrease between the egg and two-cell stage, followed by an increase by the eight-cell stage-is characteristic of a number of genes that are expressed following zygotic gene activation, which occurs during the two-cell stage in the mouse (Flach et al. 1982; Bensaude et al. 1983; Latham et al. 1991). Actin, which is not an imprinted gene, is such an example (Fig. 1B,D). Thus, the amount of Igf2r mRNA detected at the eight-cell stage reflected zygotic gene transcription and could not be attributed to maternal mRNA.

\section{Igf $2 \mathrm{r} m R N A$ and protein expression in androgenones and gynogenones}

To determine whether parental-specific imprinting mod-
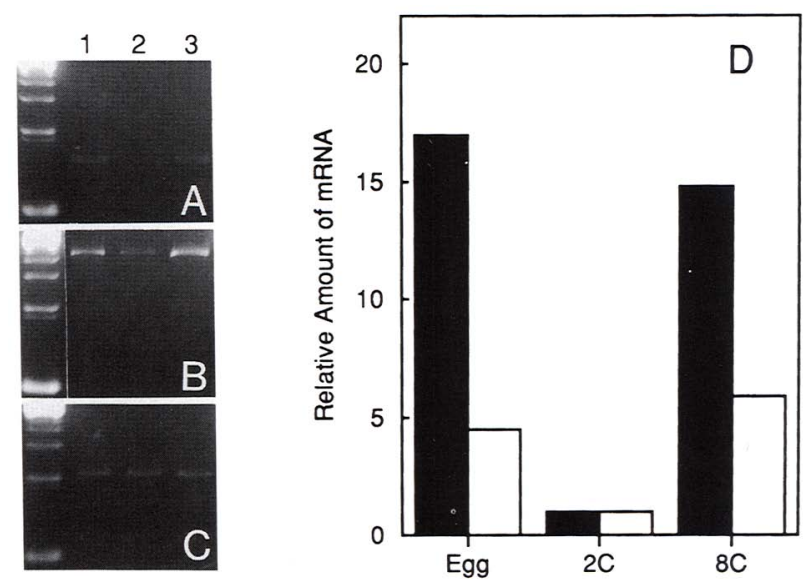

Figure 1. Changes in the relative amounts of $I g f 2 r$ and $\beta$-actin mRNAs during preimplantation development. $(A)$ Ethidium bromide-stained gel of endogenous 186-bp diagnostic Igf2r fragment. $(B)$ Ethidium bromide-stained gel of endogenous 539-bp diagnostic $\beta$-actin fragment. $(C)$ Ethidum bromide-stained gel of exogenous 257-bp $\alpha$-globin fragment. (Lanes 1-3)The unfertilized egg, two-cell, and eight-cell stages, respectively. The leftmost unnumbered lane in each gel contains molecular size standards consisting of a 123-bp ladder; the fastest migrating band corresponds to $123 \mathrm{bp}$. No diagnostic bands were observed when the reverse transcription reaction was omitted. RNA from 50 eggs or embryos was reverse transcribed, and 10,5 , and $5 \mathrm{em}-$ bryo equivalents subjected to PCR for analysis of Igf2r, $\beta$-actin, and $\alpha$-globin, respectively. $(D)$ Relationship between the relative amount of Igf2r mRNA and actin mRNA, and different developmental stages. The ratio of the number of cpm present in the Igf2r or actin diagnostic fragments to that in the globin fragment was calculated for each developmental stage. The value for the two-cell embryo was set at 1 and the values of the other stages were expressed relative to it. (Solid bars) Igf2r; (open bars) actin. ifications that occur during gametogenesis are sufficient to affect Igf2r gene expression in the preimplantation embryo, we compared the relative levels of $\lg f 2 r$ mRNA in two-cell and eight-cell androgenones, gynogenones, and normal embryos. We chose this approach rather than using interspecies hybrids that permit the expression of maternal and paternal alleles to be distinguished by restriction length polymorphisms because using nuclear transplant embryos eliminates the possibilities of differential modification of parental alleles by egg modifier factors or postfertilization interactions between maternal and paternal genomes.

As above, two-cell embryos of all three classes expressed very little Igf2r mRNA (Fig. 2A). In contrast, eight-cell embryos of all three classes contained a significant amount of Igf2r mRNA (Fig. 2A). Quantitative analysis of the PCR amplicons revealed that androgenetic eight-cell embryos exhibited an $\sim 40$-fold greater amount of Igf2r mRNA/embryo (Igf $2 r / g l o b i n=4.39$ ) than androgenetic two-cell embryos $($ Igf2r/globin $=0.11)$. Furthermore, the amount of Igf2r mRNA/eight-cell embryo was similar among all three classes (Fig. 3).

Failure to detect Igf2r mRNA in the two-cell androgenones and gynogenones, and the reduced amount detected in normal two-cell embryos could not be attributed to inadequate RT-PCR conditions, as both actin and exogenously added globin mRNAs were detected in all three classes of two-cell embryos (Fig. 2C,E). As a control for correct pronuclear identification, we also assayed expression of Xist RNA in androgenones, gynogenones, and normal embryos. Xist is expressed exclusively from the paternal $X$ chromosome beginning at the eight-cell stage (Kay et al. 1993) and so should not be expressed in gynogenones. As expected, androgenones and control embryos expressed Xist at the eight-cell stage, but not the two-cell stage, whereas very little Xist mRNA was detected in either two-cell or eight-cell gynogenones (Figs. 2D and 3). The $>20$-fold lower Xist/ globin ratio in gynogenones as compared with androgenones or controls indicated a maximum error of $5 \%$ in pronuclear identification or, more likely, a low but detectable level of expression of Xist in eight-cell gynogenones. Thus, incorrect pronuclear identification could not account for the observed $I g f 2 r$ expression in androgenones.

To determine whether the mRNA detected in androgenones at the eight-cell stage could support the expression of IGF2R, we examined androgenetic, gynogenetic, and normal embryos at the eight-cell stage for the presence of IGF2R using a specific rabbit polyclonal antiserum (C-1; Hartshorn et al. 1989). As with the RT-PCR analysis, immunocytochemical analysis of normal eggs, two-cell, and eight-cell stage embryos revealed detectable expression of the IGF2R in the egg, reduced expression in the two-cell embryo, and elevated IGF2R expression at the eight-cell stage (Fig. 4A). Our finding that IGF2R was present in the egg differed from a previous report (Harvey and Kaye 1991), and this difference was most likely attributable to our use of permeabilized embryos; nonpermeabilized embryos were used by Harvey 


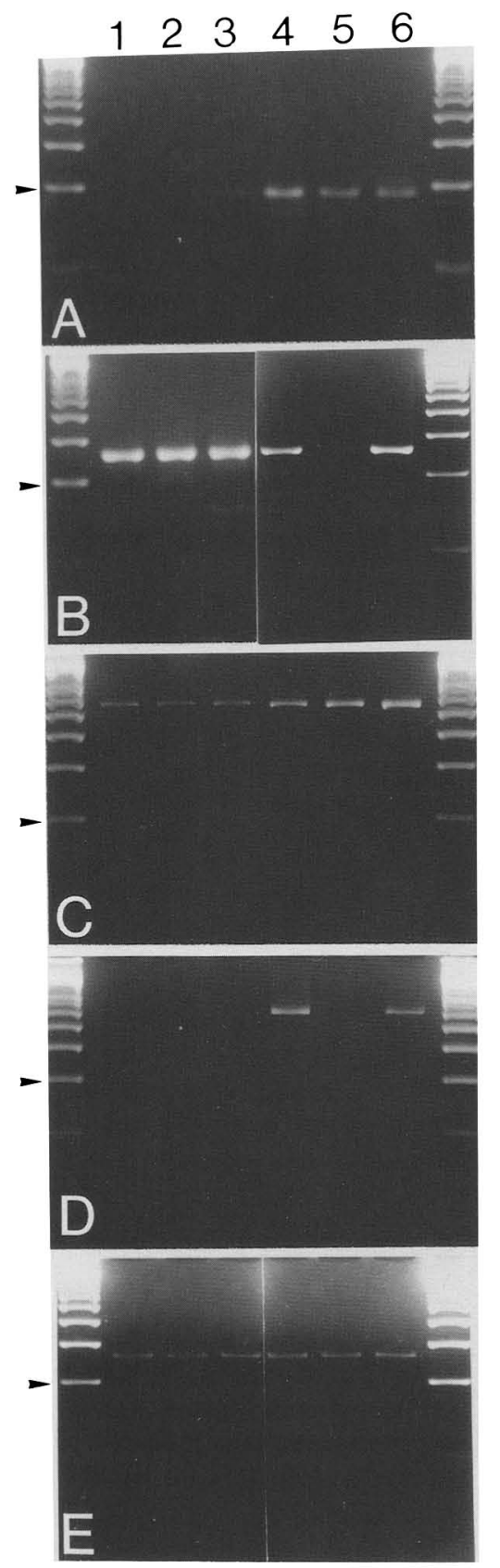

Figure 2. Expression of $I g f 2 r, I g f 2$, actin, and Xist RNAs in androgenetic, gynogenetic, and normal two-cell and eight-cell embryos. (A) Igf2r; $(B) \lg f 2 ;(C)$ actin; $(D) X i s t ;(E)$ exogenously added globin. (Lanes 1-3) two-cell embryos; (lanes 4-6) eightcell embryos. (Lanes 1,4) Androgenones; (lanes 2,5) gynogenones; (lanes 3,6) normal embryos. The two outermost lanes show a 100 -bp ladder. The arrowhead points to the 200 -bp marker.

and Kaye (1991). Permeabilization, which permits the detection of intracellular receptor, also facilitates IGF2R detection in cultured cells (Hartshorn et al. 1989). The sharp reduction in immunofluorescence that occurred between the egg and two-cell stage indicated that al- though there was some maternally derived IGF2R in the egg, this protein contributed very little, if any, to the intense fluorescence observed at the eight-cell stage. The punctate pattern of staining observed in the egg and eight-cell stage embryo was consistent with the intracellular distribution reported previously for cultured cells (Hartshorn et al. 1989) and both androgenones and gynogenones exhibited this punctate pattern of immunofluorescent staining at the eight-cell stage (Fig. 4C,D). Moreover, all of the eight-cell androgenones and gynogenones stained positively with an intensity which was similar to that observed with normal eight-cell embryos. Androgenones also expressed the receptor at the blastocyst stage (Fig. 4E).

To verify further that IGF2R expression in androgenones was attributable to expression of the paternally derived alleles, androgenetic embryos from C57BL/6 eggs fertilized by $\mathrm{T}^{\text {hp }}$ heterozygous mutant males (McGrath and Solter 1984b) were analyzed for IGF2R expression by immunofluorescence. Approximately one-fourth of such embryos should be homozygous for the $\mathrm{T}^{\mathrm{hp}} \mathrm{de}$ letion and so lack a gene encoding the IGF2R. Of 36 such androgenones subjected to immunofluorescent staining, 29 showed significant staining and 7 showed only very low, background fluorescence (data not shown). This additional evidence is consistent with the interpretation that the expression of the $I g f 2 r$ gene in androgenones was mediated by the paternally derived genes.

Taken together, these results indicate that the Igf2r gene is transcribed, the mRNA accumulates in androgenetic eight-cell embryos, and the receptor is expressed at both the eight-cell and blastocyst stages. Because androgenones contain only paternally derived chromosomes, these results indicate that paternal Igf2r genes can be

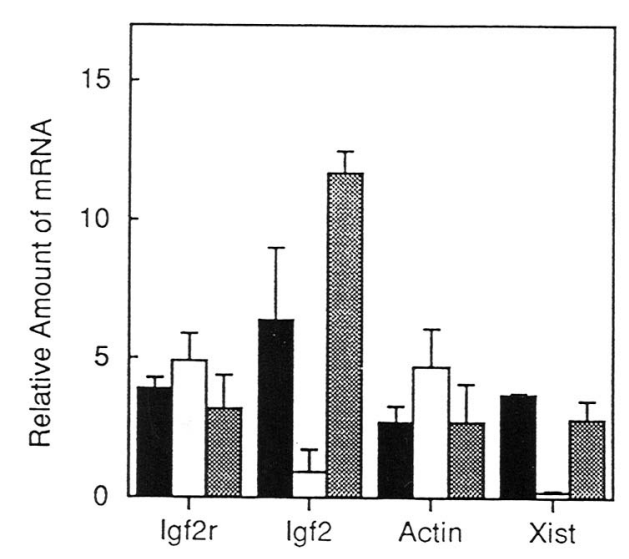

Figure 3. Histogram summarizing pooled data from multiple experiments comparing the expression of $I g f 2 r, I g f 2$, actin, and $X$ ist RNAs in androgenetic, gynogenetic, and normal eight-cell embryos. (Solid bars) androgenones; (open bars) gynogenones; (stippled bars) normal embryos. Data are expressed as the mean \pm S.E.M. Where the mean is the ratio of the number of $\mathrm{cpm}$ in the amplicon of each mRNA divided by the number of cpm in the globin amplicon. The number of experiments for Igf2r, Igf2, actin, and Xist was 5, 2, 3, and 2, respectively. 
Figure 4. Immunocytochemical analysis of IGF2R in androgenones, gynogenones, and control embryos. $(A)$ Field of unfertilized eggs, two-cell, and eight-cell control embryos stained with the IGF2R antiserum. Note that a reduced intensity of staining is observed between the unfertilized egg and two-cell stages and that this intensity increases by the eight-cell stage. The arrowheads point to a representative egg, two-cell embryos $(2 C)$, and eight-cell embryo $(8 C) .(B)$ Field of unfertilized eggs, two-cell, and eight-cell control embryos stained with the immunodepleted IGF2R antiserum. Note the reduction in the intensity of staining, when compared with the embryos shown in $A$. The arrowheads point to a representative egg, two-cell embryo (2C), and eight-cell embryo $(8 \mathrm{C})$. The intense staining material adjacent to the $8 \mathrm{C}$ embryo is attributable to nonspecific staining of debris. $(C)$ Eight-cell androgenone. The arrows point to punctate regions of immunofluorescence characteristic of IGF2R staining. $(D)$ Eight-cell gynogenone. $(E)$ Androgenetic blastocyst.

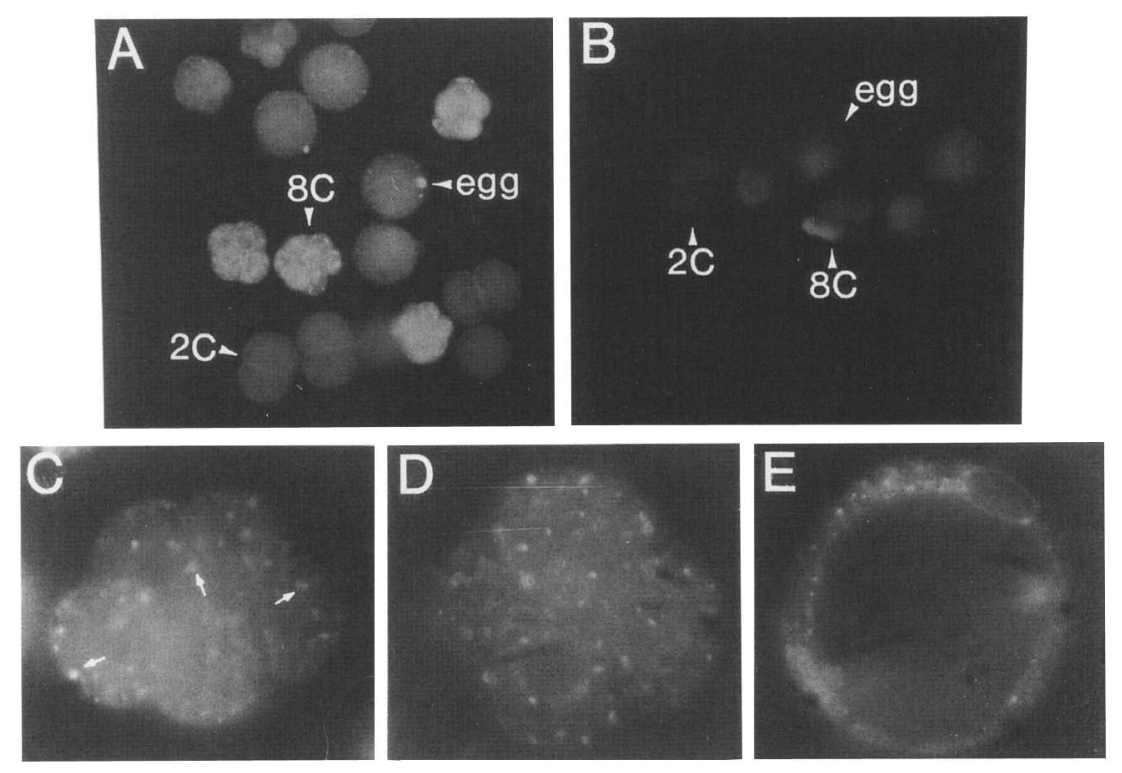

expressed during preimplantation mouse development and therefore are not inactivated as a consequence of their paternal imprint.

\section{Igf $2 \mathrm{mRNA}$ expression in gynogenones and parthenogenones}

To test whether absence of regulation by imprinting in preimplantation embryos was either a specific property of the Igf2r gene or restricted to paternally imprinted genes, we examined expression of the maternally imprinted Igf2 gene in gynogenones (Figs. 2B and 3). Gynogenones appeared to have less Igf2 mRNA than either androgenones or control embryos at the eight-cell stage. This would be consistent with lack of expression of maternal Igf2 alleles due to imprinting, as apparently occurred with Xist gene expression (Figs. 2D and 3). In contrast to the situation with Xist, for which no RNA was detected in the egg or two-cell stage embryo, and in contrast to a previous report (Rappolee et al. 1992), we detected a substantial amount of Igf2 mRNA in both eggs (data not shown) and androgenetic, gynogenetic, and normal two-cell embryos (Fig. 2B). Moreover, for androgenones, gynogenones, and control embryos, more Igf2 mRNA was present at the two-cell stage than at the eight-cell stage (Fig. 2B). For example, two-cell androgenones contained about four times more Igf2 mRNA than eight-cell androgenones. Thus, the differences in the amount of Igf2 mRNA observed between gynogenetic, androgenetic, and normal eight-cell embryos may have arisen from differences in rates of development or rates of maternal Igf2 mRNA degradation. Consequently, we could not conclude that the lower Igf2 mRNA abundance in gynogenones reflected imprinting.
The aforementioned results indicated that we could not assess the effect of imprinting on Igf2 gene expression at the eight-cell stage or before. Since we could conclude, however, that most of the maternal Igf2 mRNA for the gynogenone was degraded by the end of the eightcell stage, we examined the effect of imprinting on Igf2 gene expression at the later blastocyst stage. For these experiments, we used parthenogenetically activated eggs in order to obtain readily sufficient numbers of two-, eight-cell, and blastocyst stage embryos (Figs. 5 and 6). As with the gynogenones, we observed more $(\sim 43 \%)$ Igf2 mRNA at the two-cell stage than at the eight-cell stage (Figs. 5B and 6). In addition, there was, however, about 2.3-fold more Igf2 mRNA expressed in parthenogenetic blastocysts than parthenogenetic eight-cell embryos (Figs. 5B and 6). The amounts of Igf2r and actin mRNA also increased between the two-cell and blastocyst stages as expected (Figs. $5 \mathrm{~A}, \mathrm{C}$ and 6). Immunosurgically isolated parthenogenetic inner cell masses also expressed Igf2 mRNA (data not shown). Thus, the absence of regulation by genomic imprinting observed with the $I g f 2 r$ gene was not a specific feature of that gene.

Taken together, these results indicate that the Igf2 gene is transcribed and the mRNA accumulates in parthenogenetic blastocysts. Because parthenogenones contain only maternally derived chromosomes, these results indicate that maternal Igf2 genes can be expressed during preimplantation mouse development and therefore are not inactivated as a consequence of the maternal imprint.

\section{Discussion}

The $I g f 2 r$ and $I g f 2$ genes are reciprocally imprinted and expressed exclusively from the maternal and paternal ge- 


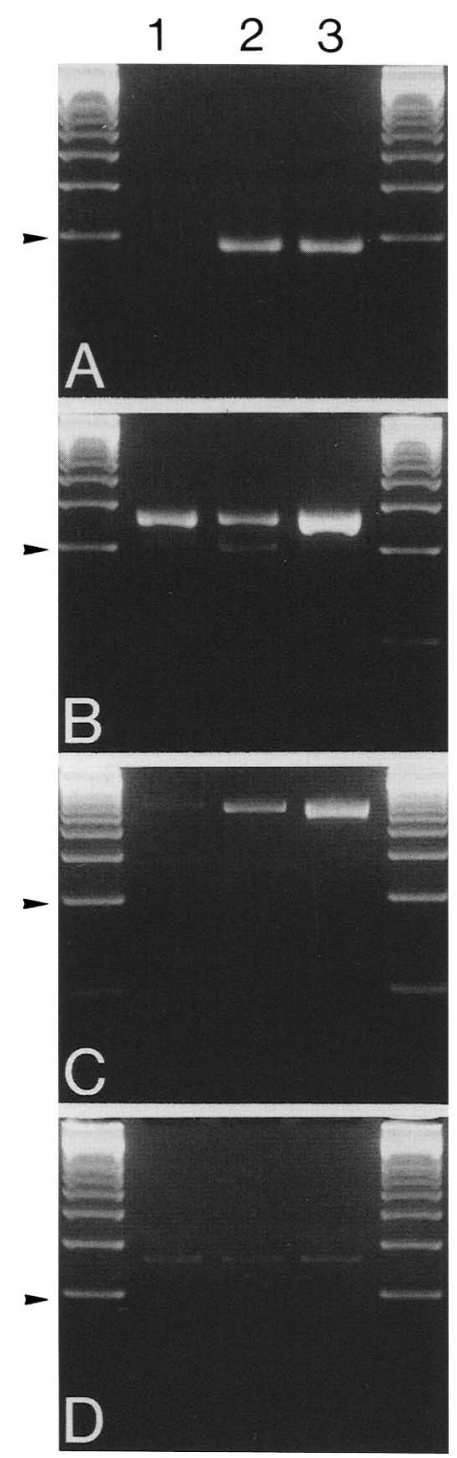

Figure 5. Patterns of expression of $I g f 2 r, I g f 2$, and actin in parthenogenetic embryos. (Lanes 1-3) Two-cell, eight-cell, and blastocyst stage embryos, respectively. $(A) \operatorname{lgf} 2 r ;(B) \operatorname{Igf2} ;|C|$ actin; $(D)$ exogenously added globin. The molecular weight markers are as in Fig. 2. The diagnostic amplicon corresponds to the major, slower migrating band; only this band was used for quantification.

nomes, respectively, in most fetal and adult tissues. Thus, during fetal development and in the adult, genomic imprinting of these two genes is translated into differences in transcription of maternal and paternal alleles. We report here an important and previously undocumented feature of regulation of imprinted genesnamely, that for both of these reciprocally imprinted genes, both maternal and paternal alleles can be expressed during preimplantation development in the mouse. This is revealed as an increase in expression at the mRNA level for both genes, as well as the protein level for the IGF2R gene in developing preimplantation embryos that contain exclusively either paternal or maternal chromsomes. The observation that the appropriate stage-specific increases in expression of both genes occur in both classes of embryos is indicative of bona fide developmentally regulated activation and expression of both alleles rather than unregulated "leaky" expression. Thus, although these genes are endowed with a genomic imprint during gametogenesis that regulates allelic expression during fetal and adult life, this imprint does not by itself regulate allelic expression during preimplantation development. Furthermore, our observation indicates that the differences in methylation observed between maternal and paternal genomes at the time of fertilization are not sufficient to regulate allelic expression.

Inactivation of paternally imprinted genes postfertilization may be indicative of an ongoing process that initiates at fertilization and continues thereafter. This process may begin with modifications mediated by egg modifier factors, which affect both transgene expression (Surani et al. 1990; Engler et al. 1991) and development of androgenones (Latham and Solter 1991), and then continue during later stages as the paternal patterns of chromatin structure and DNA methylation become established. It is also possible that interactions between maternal and paternal genomes during early embryogenesis or the presence of maternally derived $\mathrm{X}$ chromosomes might contribute to such postfertilization modifications. Such interactions would not occur in androgenones, gynogenones, or parthenogenones. The paternal patterns of methylation of certain transgenes and of the Igf2r locus itself (region 1) are not present at fertilization but, instead, arise following implantation (Chaillet et al. 1991; Stoger et al. 1993|. Maternal patterns of methylation of certain transgenes, and of the Igf2r gene itself, are present in the egg and at fertilization (Chaillet et al.

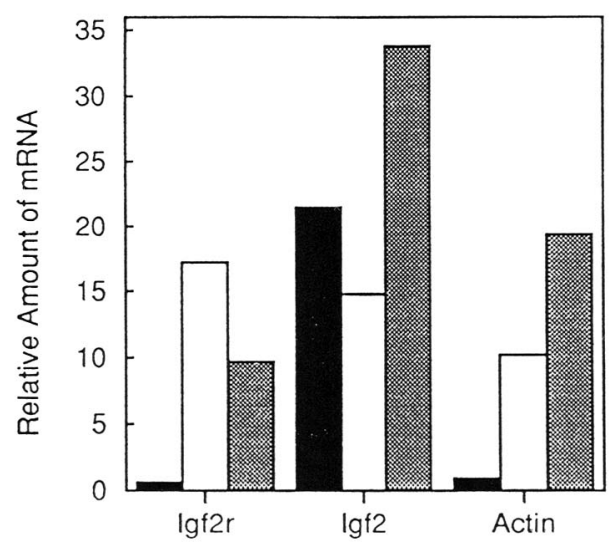

Figure 6. Histogram summarizing $I g f 2 r, I g f 2$, and actin expression in parthenogenetic embryos. (Solid bars) Two-cell embryos; (open bars) eight-cell embryos; (stippled bars) blastocysts. The data, which are derived from the gels shown in Fig. 5, are expressed as the ratios of the number of cpm in the amplicon of each mRNA divided by the number of cpm in the globin amplicon. 
1991; Stoger et al. 1993). The allele-specific patterns of methylation of the Igf2 and H19 genes seen in adult cells are not present in gametes and early cleavage-stage embryos (Brandeis et al. 1993). Thus, the allele-specific patterns of methylation of all three of these endogenously imprinted genes are acquired progressively during embryogenesis. Our data indicate that the acquisition of these methylation patterns may be essential to achieve selective allelic expression.

It has been suggested (Stoger et al. 1993) that the maternal-specific methylation in region 2 of the Igf2r gene promoter is necessary for expression, as methylation at this locus is present at fertilization. Our data, however, suggest that the maternal methylation pattern (region 2) of the Igf2r gene is not essential for gene expression in the preimplantation embryo, as paternal alleles, which lack both the region 2 and region 1 methylation modifications, are expressed in androgenones. Because our data indicate that functional inactivation of the $I g f 2 r$ gene occurs postfertilization, it is more likely that the maternal methylation in region 2 either enhances expression or prevents inactivation of this allele while paternal-specific methylation of region 1 accompanies or follows overt inactivation of the paternal allele.

Given the genetic data that demonstrate that imprinting occurs during gametogenesis (Forejt and Gregorova 19921, the simplest interpretation of our data is that imprinting and subsequent inactivation of a gene comprise two distinct events that are separable both spatially and temporally. This would be consistent with the original definition of chromosomal imprinting put forth by Crouse (1960) as a mark that the cell can use to distinguish maternal and paternal alleles. Although imprinted genes in mammals have been historically defined in a functional sense, our data suggest that the functional state of an imprinted gene depends upon the cellular context within which gene expression is assayed. We propose that the genomic imprint, when defined as a chromosomal mark that distinguishes maternal and paternal alleles, does not by itself determine the functional state of a gene. Rather, a genomic imprint may provide a bias for inactivation of one allele by other processes during later development, and this inactivation is likely to involve the establishment of the complete allele-specific patterns of methylation (Brandeis et al. 1993). The low level of maternal Igf2 allelic expression (Sasaki et al. 1992) indicates that when this inactivation occurs, it need not be absolute. Because the genomic imprint that is present in the gamete is apparently not sufficient to inactivate a gene, we suggest that specific regulatory factors that recognize the imprint are required to inactivate the imprinted allele. Such factors could be expressed in a stage-specific or tissue-specific manner and this could account for the delayed inactivation of the maternal Igf2 allele and paternal Igf2r allele shown here, as well as the contribution of egg modifiers (Surani et al. 1990; Engler et al. 1991; Latham and Solter 1991), expression of the maternal Igf2 gene in select tissues (DeChiara et al. 1991), expression of the H19 gene in human androgenetic trophoblasts (Mutter et al. 1993), differences in
DNA methylation and chromatin state among imprinted genes (Sasaki et al. 1992; Ferguson-Smith et al. 1993), and selective paternal $\mathrm{X}$ chromosome inactivation in extraembryonic cells and early somatic cells in the absence of hypermethylation and heterochromatization (Kaslow et al. 1987; Lock et al. 1987). Lack of expression of such factors could also contribute to loss of imprinting (Ogawa et al. 1993; Rainier et al. 1993).

Our data can also be interpreted within the broader context of the overall function that imprinting serves in development. It has been suggested that imprinting in mammals permits a necessary incremental reduction in the expression of certain genes that might not be otherwise achievable because of an inability of certain genes to be transcriptionally modulated with a sufficient degree of control (Solter 1988). By analogy with paternal X inactivation in extraembryonic tissues, this need might in part relate to demands of placentation, although a similar need might also exist in somatic tissues /Solter 1988). Imprinting provides a means by which the cell can consistently reduce its expression of certain genes by one-half. If imprinting evolved to allow such an incremental regulation of gene expression in specific tissues, then those tissues would by necessity express specific factors that recognize an imprint and then promote allelic inactivation. The prediction from such a system would be that if a gene that is normally regulated in this way is also expressed in the preimplantation embryo, before expression of the factors that promote allelic inactivation, then both alleles should be expressed.

\section{Materials and methods}

Mouse embryo collection and culture

Mice were obtained from Harlan Sprague-Dawley. Embryos were isolated at the one-cell stage from $\mathrm{C} 57 \mathrm{BL} / 6$ females $6-8$ weeks of age that had been mated to $\mathrm{C} 57 \mathrm{BL} / 6$ males and cultured as described (Latham and Solter 1991). Nuclear transplantation was performed as described (McGrath and Solter 1983; Latham and Solter 1991). Embryos were cultured until $\sim 43 \mathrm{hr}$ (two-cell) or $76 \mathrm{hr}$ (eight-cell) post-hCG injection when they were lysed for PCR analysis. For the C57BL/6 strain, the culture conditions employed allow a high efficiency of development of both androgenones and gynogenones to the compacted eightcell stage, typically $80-100 \%$ for androgenones and $95-100 \%$ for gynogenones. Embryos that blocked in development were excluded from analyses. Thus, possible effects of differences in developmental potentials of the different classes of embryos were largely avoided. Parthenogenetic embryos were obtained following ethanol activation of B6D2 eggs (Hogan et al. 1986). Two-cell, eight-cell, and blastocyst stage embryos were collected 27,52 , and $93 \mathrm{hr}$, respectively, postactivation. Immunosurgery of blastocysts was performed as described previously (Solter and Knowles 1975).

\section{$R T-P C R$}

Unless stated otherwise, all solutions were prepared with water that had been treated with $0.1 \%$ diethylpyrocarbonate. For lysis, embryos were transferred in a minimal volume to a chilled 0.6- $\mathrm{ml}$ microcentrifuge tube on ice containing 20-100 $\mu \mathrm{l}$ of lysis buffer $(100 \mu \mathrm{l}$ of $4 \mathrm{M}$ guanidine thiocyanate, $0.1 \mathrm{M}$ Tris $-\mathrm{HCl}(\mathrm{pH}$ 
7.41, $1 \mathrm{M}$ 2-mercaptoethanol, and $0.2 \mu \mathrm{g} / \mu \mathrm{l}$ Escherichia coli rRNA), the sample vortexed vigorously, and stored at $-70^{\circ} \mathrm{C}$. Prior to isolation of the RNA, the tubes were thawed on ice, and $0.0125 \mathrm{pg}$ of rabbit globin mRNA (BRL) was added per embryo. This mRNA served as an internal control for RNA recovery and efficiency of the RT-PCR reactions (see below). The RNA was precipitated by the addition of $8 \mu \mathrm{l}$ of $1 \mathrm{M}$ acetic acid, $5 \mu \mathrm{l}$ of 2 M potassium acetate, and $60 \mu \mathrm{l}$ of $100 \%$ ethanol. The samples were precipitated overnight at $-20^{\circ} \mathrm{C}$.

The nucleic acid was collected by centrifugation at $10,000 \mathrm{~g}$ for $15 \mathrm{~min}$ at $4^{\circ} \mathrm{C}$. The large off-white pellets were then washed once at $4{ }^{\circ} \mathrm{C}$ with cold $75 \%$ ethanol. The final wash was removed carefully with a pipette, and the pellets were air-dried just to the point of dryness; overdrying was avoided as the resulting pellets were virtually impossible to resuspend. The pellets were resuspended in $20 \mu \mathrm{l}$ of resuspension solution (RS: $40 \mathrm{~mm}$ Tris- $\mathrm{HCl}$ at $\mathrm{pH} 7.9,10 \mathrm{mM} \mathrm{NaCl}, 6 \mathrm{~mm} \mathrm{MgCl}_{2}$ ). DNA was degraded by incubating the sample with 1 unit of RQ1 DNase (Promega) for $30 \mathrm{~min}$ at $37^{\circ} \mathrm{C}$. Following the addition of a second volume of RS, the samples were extracted with $40 \mu \mathrm{l}$ of RS saturated phenol (Amresco). The samples were vortexed, centrifuged for 3 min at $10,000 \mathrm{~g}$, and the aqueous phase was transferred to a $0.5-\mathrm{ml}$ microcentrifuge tube. Five microliters of $3 \mathrm{M}$ potassium acetate ( $\mathrm{pH} 5.2)$ and 3 volumes of $100 \%$ ethanol were added and the RNA precipitated overnight at $-20^{\circ} \mathrm{C}$.

The RNA was again recovered by centrifugation, the supernatant removed, and the pellet incubated for $10 \mathrm{~min}$ in $75 \%$ ethanol at room temperature. The samples were centrifuged for $15 \mathrm{~min}$ and the very small, glassy pellets were air-dried just to dryness. The pellets were dissolved in $5.5 \mu$ l of water containing $2 \mathrm{U} / \mu \mathrm{l}$ of RNasin (Promega) and $0.5 \mu \mathrm{l}$ was removed to determine RNA recovery by measuring the absorbance at $260 \mathrm{~nm}$. The recovery of carrier RNA, and by inference, of embryo RNA, usually ranged between 85 and $100 \%$.

Reverse transcription was conducted on 50 egg or embryo equivalents. The reactions were carried out in $20 \mu \mathrm{l}$ of $25 \mathrm{~mm}$ Tris- $\mathrm{HCl}(\mathrm{pH} 8.3), 75 \mathrm{mM} \mathrm{KCl}$, and $3 \mathrm{mM} \mathrm{MgCl}_{2}$ containing 1 mM each of dATP, dGTP, dCTP, dTTP, $10 \mathrm{~mm}$ dithiothreitol, 1 $\mathrm{U} / \mu \mathrm{l}$ of RNasin, and $0.4 \mu \mathrm{g}$ of oligo/ $\left(\mathrm{dT}_{12-18}\right)$ (Pharmacia). The tubes (Gene Amp thin-walled tubes) were incubated at $37^{\circ} \mathrm{C}$ for $2 \mathrm{~min}, 200$ units of reverse transcriptase (Superscript, BRL) were added, and the tubes were transferred to a 9600 PCR thermocycler (Cetus-Perkin Elmer). Reverse transcription was conducted for $1 \mathrm{hr}$ at $42^{\circ} \mathrm{C}$. The samples were then heated for $5 \mathrm{~min}$ at $99^{\circ} \mathrm{C}$ and placed on ice. At this point the samples were either used immediately for PCR or stored at $-20^{\circ} \mathrm{C}$.

The PCR was performed in $100 \mu \mathrm{l}$ of $10 \mathrm{mM}$ Tris- $\mathrm{HCl}(\mathrm{pH} 8.3)$, containing $50 \mathrm{mM} \mathrm{KCl}, 1.45 \mathrm{mM} \mathrm{MgCl}, 0.2 \mathrm{~mm}$ each of the four dNTPs, $5 \mu \mathrm{Ci}$ of $\left[\alpha^{-32} \mathrm{P}\right] \mathrm{dCTP}$ (sp. act. $3000 \mathrm{Ci} / \mathrm{mmole}$, Amersham), 2.5 units of AmpliTaq polymerase (Perkin-Elmer Cetus), 20 pmoles $(0.4 \mu \mathrm{M})$ each of the appropriate $3^{\prime}$ and $5^{\prime}$ primers, and a volume of the reverse transcription reaction. When Igf2r, Igf2, $X$ ist, $\beta$-actin, or $\beta$-globin cDNAs were amplified, this volume was equivalent to $10,10,5,5$, or 5 embryos, respectively. PCR primers used and the size of the diagnostic amplicons are shown in Table 1.

The basic PCR program used was $95^{\circ} \mathrm{C}$ for $1 \mathrm{~min}$, followed by a cycle program of $95^{\circ} \mathrm{C}$ for $10 \mathrm{sec}$ and $60^{\circ} \mathrm{C}$ for $15 \mathrm{sec}$. The last cycle was concluded with a 6 -min extension at $60^{\circ} \mathrm{C}$. For each set of primers, semilog plots of the amount of radiolabeled amplicon product as a function of cycle number was used to determine the range of cycle number over which amplicon production was linear on such plots (data not shown). This region of linearity varied for each set of primers due to differences in efficiency of amplification. The number of cycles was 50, 50, 35, 33 , and 29 for Igf2r, Igf2, actin, Xist, and globin, respectively. It should be noted that because the absolute efficiency of amplification for each set of primers during each cycle is not known, one cannot compare the abundance of one mRNA to that of another mRNA. The assay can be used, however, to compare relative abundances of one mRNA among different samples (Temeles et al. 1993).

Following PCR, the tubes were chilled briefly on ice and centrifuged to collect any condensation. Then $25 \mu \mathrm{l}$ was removed and treated with $2 \mu \mathrm{l}$ of a $20 \mu \mathrm{g} / \mathrm{ml}$ solution of RNase A (Worthington) for $10 \mathrm{~min}$ at room temperature to digest any remaining carrier RNA. After the addition of $5 \mu \mathrm{l}$ of $6 \times$ loading buffer $10.25 \%$ bromphenol blue in $40 \%$ sucrose $), 13 \mu \mathrm{l}$ of each sample was subjected to electrophoresis on a $4 \%$ agarose gel (Manejwala et al. 1991). The gels were photographed under UV light, the bands were excised with a clean razor blade, and the incorporation of radiolabeled dCTP in each gel slice was determined by Cerenkov counting. Generation of the diagnostic fragment was strictly dependent on the presence of RNA in the reverse transcription reaction, as when the reverse transcription step was omitted, no amplified fragments were observed (data not shown). In addition, amplicon identities were confirmed by appropriate restriction digests of PCR products (data not shown).

Table 1. Primers used for RT-PCR and size of diagnostic amplicon

\begin{tabular}{|c|c|c|c|}
\hline Gene $^{a}$ & Primer & Primer sequence & $\begin{array}{l}\text { Amplicon } \\
\text { size (bp) }\end{array}$ \\
\hline$\alpha$-globin & 5 & 5'-GCAGCCACGGTGGCGAGTAT-3' & 257 \\
\hline$\alpha$-globin & 3 & 5'-GTGGGACAGGAGCTTGAAAT-3' & \\
\hline$\beta$-actin & 5 & 5'-GTGGGCCGCTCTAGGCACCAA-3' & 539 \\
\hline$\beta$-actin & 3 & 5'-CTCTTTGATGTCACGCACGATTTC-3' & \\
\hline Igf2 & 5 & $5^{\prime}$-GGCCCCGGAGAGACTCTGTGC- $3^{\prime}$ & 266 \\
\hline Igf2 & 3 & 5'-GCCCACGGGGTA TCTGGGGAA-3' & \\
\hline $\lg f 2 r$ & 5 & 5'-TGTACACTCTTCTTCTCCTGGCA-3' & 186 \\
\hline $\operatorname{Igf} 2 r$ & 3 & 5'-ACAGATGTTGATGTAGAAGTCAGG-3' & \\
\hline Xist & 5 & 5'-ACTGCCAGCAGCCTATACAG-3' & 578 \\
\hline Xist & 3 & 5'-GTTGATCCTCGGGTCATTTA-3' & \\
\hline
\end{tabular}

The references for the $\alpha$-globin (rabbit) and $\beta$-actin primer sequences are Cheng et al. (1986) and Clonetech, respectively. References for the sequences of the Igf2 and Igf2r primers can be found in Rappolee et al. (1992). The reference for the sequences of the Xist primers is Kay et al. (1993). 


\section{Immunofluorescence staining of eggs and embryos}

Zonae pellucidae were removed with acid Tyrode's buffer in agarose-coated dishes, and the eggs or embryos were fixed for 45 min in $2 \%$ paraformaldehyde in phosphate-buffered saline (PBS). After fixation, the embryos were treated for $15 \mathrm{~min}$ with $50 \mathrm{mM} \mathrm{NH} \mathrm{NCl}_{4}$ in PBS, permeabilized for $10 \mathrm{~min}$ at room temperature in $0.1 \%$ Triton $\mathrm{X}-100$, and washed in M2 medium. They were incubated sequentially in $\mathrm{C}-1$ antiserum diluted 1 : 1000 in $\mathrm{M} 2$ for $30 \mathrm{~min}$ at $37^{\circ} \mathrm{C}$, biotinylated donkey anti-rabbit immunoglobulin (Amersham) diluted 1:200 in M2 for $30 \mathrm{~min}$ at $37^{\circ} \mathrm{C}$, and streptavidin-conjugated with Texas Red (Amersham) diluted $1: 100$ in $\mathrm{M} 2$ for $30 \mathrm{~min}$ at $37^{\circ} \mathrm{C}$. After staining, the embryos were mounted in M2 medium under oil for fluorescence visualization of antigen

\section{Acknowledgments}

This research was supported by grants from the National Institutes of Health (GM 49489 to K.E.L. and a National Cancer Institute Cancer Center Support grant (P30 CA 12227) to the Fels Institute, and HD 22681 to R.M.S.). We thank Gretchen Temeles for establishing many of the conditions for the RTPCR assay, and Greg Kopf for constructive criticisms. We are especially grateful to Davor Solter for his instructive comments and discussions of the manuscript.

The publication costs of this article were defrayed in part by payment of page charges. This article must therefore be hereby marked "advertisement" in accordance with 18 USC section 1734 solely to indicate this fact.

\section{References}

Barlow, D.P., R. Stoger, B.G. Hermann, K. Saito, and N. Schweifer. 1991. The mouse insulin-like growth factor type- 2 receptor is imprinted and closely linked to the Tme locus. Nature 349: 84-87.

Bartolomei, M.S., S. Zemei, and S.M. Tilghman. 1991. Parental imprinting of the mouse $H 19$ gene. Nature 351: 153-155.

Bartolomei, M.S., A.L. Webber, M.E. Brunkow, and S.M. Tilghman. 1993. Epigenetic mechanisms underlying the imprinting of the mouse H19 gene. Genes \& Dev. 7: 1663-1673.

Barton, S.C., M.A.H. Surani, and M.L. Norris. 1984. Role of paternal and maternal genomes in mouse development. $\mathrm{Na}$ ture 311: 374-376.

Bensaude, O., C. Babinet, M. Morange, and F. Jacob. 1983. Heat shock proteins, first major products of zygotic gene activity. Nature 305: 331-333.

Brandeis, M., T. Kafri, M. Ariel, J.R. Chaillet, J. McCarrey, A. Razin, and H. Cedar. 1993. The ontogeny of allele-specific methylation associated with imprinted genes in the mouse. EMBO I. 12: 3669-3677.

Chaillet, J.R., T.F. Vogt, D.R. Beier, and P. Leder. 1991. Parentalspecific methylation of an imprinted transgene is established during gametogenesis and progressively changes during embryogenesis. Cell 66: 77-83.

Cheng, J.-F., L. Raid, and R.C. Hardison. 1986. Isolation and nucleotide sequence of the rabbit globin gene cluster $\psi \zeta-\alpha 1$ $\psi \alpha$. Absence of a pair of $\alpha$-globin genes evolving in concert. I. Biol. Chem. 261: 839-848.

Crouse, H.V. 1960. The controlling element in sex chromosome behavior in Sciara. Genetics 45: 1429-1443.

DeChiara, T.M., E.J. Robertson, and A. Efstratiadis. 1991. Parental imprinting of the mouse insulin-like growth factor II gene. Cell 64: 849-859.
Doerfler, W. 1983. DNA methylation and gene activity. Annu. Rev. Biochem. 52: 93-124.

Engler, P., D. Haasch, C. Pinkert, L. Doglio, M. Glymour, R. Brinster, and U. Storb. 1991. A strain-specific modifier on mouse chromosome 4 controls methylation of independent transgene loci. Cell 65: 939-947.

Ferguson-Smith, A.C., H. Sasaki, B.M. Cattanach, and M.A. Surani. 1993. Parental-origin-specific epigenetic modification of the mouse $H 19$ gene. Nature 362: 751-755.

Flach, G., M.H. Johnson, P.R. Braude, R.A.S. Taylor, and V.N. Bolton. 1982. The transition from maternal to embryonic control in the two-cell mouse embryo. EMBO I. 1: 681-686.

Forejt, J. and S. Gregorova. 1992. Genetic analysis of genomic imprinting: An Imprintor-1 gene controls inactivation of the paternal copy of the mouse Tme locus. Cell 70: 443-450.

Grant, M., M. Zuccotti, and M. Monk. 1992. Methylation of $\mathrm{CpG}$ sites of two X-linked genes coincides with X-inactivation in the female mouse embryo but not in the germline. Nature Genet. 2: 161-166.

Hadchouel, M., H. Farza, D. Simon, P. Tiollais, and C. Pourcel. 1987. Maternal inhibition of hepatitis B surface antigen expression in transgenic mice correlates with de novo methylation. Nature 329: 454-456.

Hartshorn, M.A., C.D. Scott, and R.C. Baxter. 1989. Immunofluorescent localization of type II insulin-like growth factor receptor in rat liver and hepatoma cells. I. Endocrinol. 121: 221-227.

Harvey, M.B. and P.L. Kaye. 1991. IGF-2 receptors are first expressed at the two-cell stage of mouse development. Development 111: 1057-1060.

Hogan, B., F. Constantini, and E. Lacy. 1986. Manipulating the mouse embryo, pp. 109-110, Cold Spring Harbor Laboratory, Cold Spring Harbor, New York.

Howlett, S.K. and W. Reik. 1991. Methylation levels of maternal and paternal genomes during preimplantation development. Development 113: 119-127.

Kaslow, D.C. and B.R. Migeon. 1987. DNA methylation stablizes $\mathrm{X}$ chromosome inactivation in eutherians, but not in marsupials: Evidence for multi-step maintenance of mammalian X dosage compensation. Proc. Natl. Acad. Sci. USA 84: 6210-6214.

Kaufman, M.H., S.C. Barton, and M.A.H. Surani. 1977. Normal postimplantation development of mouse parthenogenetic embryos to the forelimb bud stage. Nature 265: 53-55.

Kay, G.F., G.D. Penny, D. Patel, A. Ashworth, N. Brockdorff, and S. Rastan. 1993. Expression of Xist during mouse development suggests a role in the initiation of $\mathrm{X}$ chromosome inactivation. Cell 72: 171-182.

Kratzer, P.G., V.M. Chapman, H. Lambert, R.E. Evans, and R.M. Liskay. 1983. Differences in the DNA of the inactive X chromosome of fetal and extraembryonic tissues of mice. Cell 33: $37-42$.

Latham, K.E. and D. Solter. 1991. Effect of egg composition on the developmental capacity of androgenetic mouse embryos. Development 113: 561-568.

Latham, K.E., J.I. Garrels, C. Chang, and D. Solter. 1991. Quantitative analysis of protein synthesis in mouse embryos. I. Extensive reprogramming at the one- and two-cell stages. Development 112: 921-932.

Leff, S.E., C.I. Brannan, M.L. Reed, T. Ozcelik, U. Francke, N.G. Copeland, and N. Jenkins. 1992. Maternal imprinting of the mouse Snrpn gene and conserved linkage homology with the human Prader-Willi syndrome region. Nature Genet. 2: 259264.

Lock, L.F., N. Takagi, and G.R. Martin. 1987. Methylation of the Hprt gene on the inactive $\mathrm{X}$ occurs after chromosome 
inactivation. Cell 48: 39-46.

McGrath, J. and D. Solter. 1983. Nuclear transplantation in the mouse embryo by microsurgery and cell fusion. Science 220: 1300-1302.

1984a. Completion of mouse embryogenesis requires both maternal and paternal genomes. Cell 37: 179-183.

- 1984b. Maternal $\mathrm{T}^{h p}$ lethality in the mouse is a nuclear, not cytoplasmic defect. Nature 308: 550-551.

Manejewala, F.M., C.Y. Logan, and R.M. Schultz. 1991. Regulation of hsp $70 \mathrm{mRNA}$ levels during oocyte maturation and zygotic gene activation in the mouse. Dev. Biol. 144: 301308.

Mutter, G.L., C.L. Stewart, M.L. Chaponot, and R.J. Pomponio. 1993. Oppositely imprinted genes $\mathrm{H} 19$ and insulin-like growth factor 2 are coexpressed in human androgenetic trophoblast. Am. J. Hum. Genet. 53: 1906-1 102.

Ogawa, O., M.R. Eccles, J. Szeto, L.A. McNoe, K. Yun, M.A. Maw, P.J. Smith, and A.E. Reeve. 1993. Relaxation of insulin-like growth factor II gene imprinting implicated in Wilms' tumour. Nature 362: 749-751.

Rainier, S., L.A. Johnson, C.J. Dobry, A.J. Ping, P.E. Grundy, and A.P. Feinberg. 1993. Relaxation of imprinted genes in human cancer. Nature 362: 747-749.

Rappolee, D.A., K.S. Sturm, O. Behrendtsen, G.A. Schultz, R.A. Pedersen, and Z. Werb. 1992. Insulin-like growth factor II acts through an endogenous growth pathway regulated by imprinting in early mouse embryos. Genes \& Dev. 6: 939952.

Reik, W., A. Collick, M. Norris, S. Barton, and M. Surani. 1987. Genomic imprinting determines methylation of parental alleles in transgenic mice. Nature 328: 248-251.

Sapienza, C., A.C. Peterson, J. Rossant, and R. Balling. 1987. Degree of methylation of transgenes is dependent on gamete of origin. Nature 328: 251-254.

Sapienza, C., T.-H. Tran, J. Pacquette, R. McGowan, and A. Peterson. 1989. A methylation mosaic model for mammalian genome imprinting. Prog. Nucleic Acids Res. Mol. Biol. 36: $145-157$.

Sasaki, H., P.A. Jones, R. Chaillet, A.C. Ferguson-Smith, S.C. Barton, W. Reik, and M.A. Surani. 1992. Parental imprinting: Potentially active chromatin of the repressed maternal allele of the mouse insulin-like growth factor II (Igf2) gene. Genes \& Dev. 6: 1843-1856.

Singer-Sam, J., M. Grant, J.M. LoBon, K. Okuyama, V. Chapman, M. Monk, and A.D. Riggs. 1990. Use of Hpall-polymerase chain reaction assay to study DNA methylation of the Pgk-1 CpG island of mouse embryos at the time of X-chromosome inactivation. Mol. Cell Biol. 10: 4987-4989.

Solter, D. 1988. Differential imprinting and expression of maternal and paternal genomes. Annu. Rev. Genet. 22: 127146.

Solter, D. and B.B. Knowles. 1975. Immunosurgery of mouse blastocyst. Proc. Natl. Acad. Sci. U.S.A. 72: 5099-5102.

Stoger, R., P. Kubicka, C.-G. Liu, T. Kafri, A. Razin, H. Cedar, and D.P. Barlow. 1993. Maternal-specific methylation of the imprinted mouse locus identifies the expressed locus as carrying the imprinted signal. Cell 73: 61-71.

Surani, M.A.H., S.C. Barton, and M.L. Norris. 1984. Development of mouse eggs suggests imprinting of the genome during gametogenesis. Nature 308: 548-550.

. 1986. Nuclear transplantation in the mouse: Heritable differences between parental genomes after activation of the embryonic genome. Cell 45: 127-136.

- 1987. Influence of parental chromosomes on spatial specificity in androgenetic - parthenogenetic chimeras in the mouse. Nature 326: 395-397.
Surani, M.A., R. Kothary, N.D. Allen, P.B. Singh, R. Fundele, A.C. Ferguson-Smith, and S.C. Barton. 1990. Genome imprinting and development in the mouse. (Suppl.) Development 89-98.

Swain, J.L., T.A. Stewart, and P. Leder. 1987. Parental legacy determines methylation and expression of an autosomal transgene: A molecular mechanism for parental imprinting. Cell 50: 719-727.

Temeles, G.L., P.T. Ram, J.L. Rothstein, and R.M. Schultz. 1994. Expression patterns of novel genes during mouse preimplantation embryogenesis. Mol. Reprod. Dev. (in press).

Thomson, J.A. and D. Solter. 1989. Chimeras between parthenogenetic, androgenetic and normal embryos: Allocation to the inner cell mass and trophectoderm. Dev. Biol. 131: 580583.

Ueda, T., K. Yamazaki, R. Suzuki, H. Fujimoto, H. Sasaki, Y. Sakaki, and T. Higashinakagawa. 1992. Parental methylation patterns of a transgenic locus in adult somatic tissues are imprinted during gametogenesis. Development 116: 831-839. 


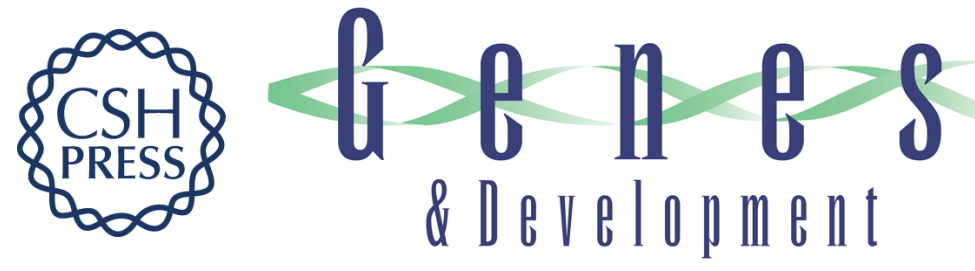

\section{Igf2r and Igf2 gene expression in androgenetic, gynogenetic, and parthenogenetic preimplantation mouse embryos: absence of regulation by genomic imprinting.}

K E Latham, A S Doherty, C D Scott, et al.

Genes Dev. 1994, 8:

Access the most recent version at doi:10.1101/gad.8.3.290

References This article cites 49 articles, 15 of which can be accessed free at: http://genesdev.cshlp.org/content/8/3/290.full.html\#ref-list-1

License

Email Alerting Service

Receive free email alerts when new articles cite this article - sign up in the box at the top right corner of the article or click here.

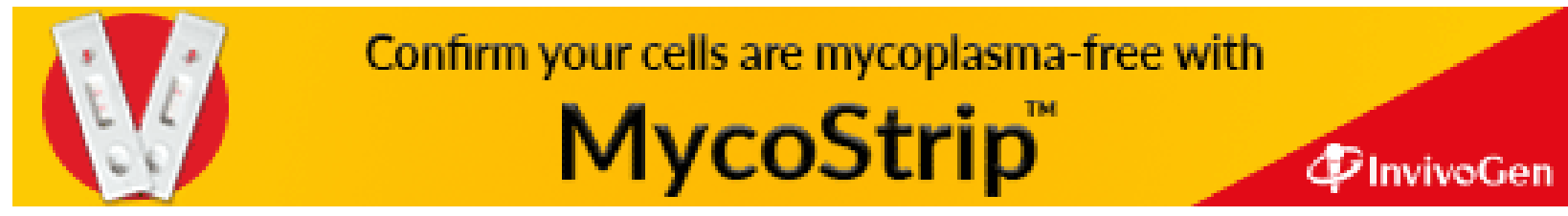

